CASE NOTE

\title{
A MEMBER'S RIGHT TO SUE ON BEHALF OF A COMPANY: STATUTORY DERIVATIVE ACTION UNDER SECTION 181A COMPANIES ACT 1965 Mohd Shuaib Ishak $v$ Celcom (M) Bhd ${ }^{1}$
}

\author{
Mushera Ambaras Khan²
}

\section{INTRODUCTION}

The case under review, Mohd Shuaib Ishak v. Celcom (M) $B h d$. , is the first reported case in Malaysia where the court has granted leave to an individual shareholder to commence a statutory derivative action. By an amendment made to the Companies Act 1965, Section 181A which came into force on 15 August 2007, ${ }^{3}$ enables current and former members and directors of a company to bring an action on behalf of the company to enforce the company's right, or intervene in proceedings to which the company is a party. ${ }^{4}$ This action, known as the statutory derivative action, was introduced to rectify the inadequacies of the common law derivative action. A derivative action is an action brought

[2008]5 MLJ 857.

Associate Professor, Ahmad Ibrahim Kulliyyah of Laws, International Islamic University Malaysia.

See the Companies (Amendment) Act 2007, Act A 1299.

Section 181A(4). The Registrar may also institute a derivative action in case of a declared company under Part IX. 
by a member on behalf of a company or where a member "steps into the shoes" of the company to enforce the company's right.

Prior to the introduction of the statutory derivative action into the Companies Act 1965, a shareholder could bring a derivative action only if his complaint falls within the accepted exceptions to the rule in Foss $v$ Harbottle. ${ }^{5}$ However, the exceptions to the rule in Foss $v$ Harbottle has been described as "complex and obscure" "6 with conflicting authority as to the exact scope of the exceptions, making it difficult to accurately state the law. ${ }^{7}$ Another obstacle to bringing a common law derivative action is the costs factor. ${ }^{8}$ Despite the fact that the common law allows a shareholder who brings a derivative action to be indemnified by the company for all costs incurred in bringing the action, ${ }^{9}$ subsequent cases limits its utility. ${ }^{10}$

In Mohd Shuaib, the plaintiff in this case is a former member of the company who ceased to be a member and a shareholder as a result of his shares being compulsorily purchased under section 34 of the Securities Commission Act $1993 .{ }^{11}$ He wishes to bring a statutory derivative action against a number of parties, including the directors of the company, Celcom in which he held shares. The court in this case examined the law in relation to statutory derivative action before granting leave to commence an action by the former member and a shareholder, Mohd Shuaib Ishak.

5 (1843) 2 Hare 261, 67 ER 189.

$6 \quad$ Brian R Cheffins, "Reforming the Derivative Action: the Canadian Experience and British Prospects” (1997) 2 Company, Financial and Insolvency Law Review 227 at 233.

$7 \quad$ Matthew Berkahn, "The Derivative Action in Australia and New Zealand: Will the Statutory Provisions Improve Shareholders' Enforcement Rights?” (1998) 10 Bond Law Review 74 at 98. See Mushera Ambaras Khan, "Minority Shareholders Remedies: Proposal for Reform for Malaysia" [2003] CLJ Ivii.

$9 \quad$ See Wallersteiner v Moir (No 2) [1975] QB 373.

10 In Smith v Croft [1986] 2 All ER 551, for example, Holton J held that the interim funding orders should not be made until after discovery, and only in cases of genuine need.

$11 \quad$ Act 498. 


\section{MOHD. SHUAIB ISHAK V. CELCOM (M) BHD.}

He was the registered owner of 500,000 ordinary shares in Celcom (Malaysia) Bhd. and he applied for leave to bring an action under section 181A(1) of the Companies Act 1965 on behalf of Celcom, against the directors of Celcom, Telekom Malaysia Bhd (Telekom) which is the ultimate holding company of Celcom, the directors of Telekom and Celcom's independent advisor, Alliance Investment Bank Berhad.

The plaintiff alleged that the defendants conspired to cause Celcom to breach its obligations under an Amended and Restated Supplemental Agreement (ARSA) entered between Celcom and DeTeAsia and two other companies. By this agreement, Celcom agreed that it would not merge its business or accept a significant new shareholder without the consent of DeTeAsia failing which, Celcom would procure a Buy Out Offer for DeTeAsia at a price of RM7 per Celcom share owned by DeTeAsia.

Telekom Malaysia (TM), Telekom Enterprise Sdn Bhd (TESB) and their parties acting in concert wished to merge Celcom's business with Telekom's cellular business and takeover Celcom. In furtherance of this aim, Telekom which by then has effective control of Celcom caused Celcom to enter into an agreement (SPA) whereby Celcom agreed to acquire 100\% of equity interest in TM Cellular Sdn Bhd from Telekom. Under the SPA, Celcom agreed to issue its shares to Telekom as consideration for the purchase made. The issuance of the shares resulted in an obligation upon Telekom, Telekom Enterprise and their parties acting in concert to make a mandatory general offer (MGO) for all the remaining shares in Celcom under the Malaysian Code on Takeovers and Mergers 1998. The Code provides that in a MGO, the shareholders of the target company must receive at least the highest price paid for the shares of the target in the previous six months preceding the triggering of the MGO. For the purpose of the MGO, the highest price at the time was RM2.75 per Celcom share which would bring the total cost for the purchase to RM3.67b.

The above transaction was made without the consent of DeTeAsia. Had the consent of DeTeAsia been sought by Celcom, DeTeAsia would have refused its consent. This would result in breach of the ARSA and Celcom would then have to procure a Buy Out Offer at RM7 as agreed. If DeTeAsia had received RM7 per Celcom share under the Buy Out Offer, the MGO would have had to be made at RM7 and the total cost to Telekom would have been RM9.34b. 
DeTeAsia commenced arbitration proceedings against Celcom in the International Court of Arbitration for the breach of the ARSA. The International Court of Arbitration awarded damages amounting to US\$177,243,679 together with interest and all costs to DeTeAsia, bringing the total amount of damages to US\$232,999,745.80.

The plaintiff contended that the damages of US\$232,999,745.80 would not have been payable to DeTeAsia if Telekom, Telekom Enterprise and parties acting in concert had not conspired to cause Telekom to breach the ARSA. The plaintiff also contended that these parties benefitted from the conspiracy with the directors of Celcom. The main loser was Celcom, which had to pay compensation to DeTeAsia while the main beneficiaries of the wrongdoings have been Telekom, Telekom Enterprise and parties acting in concert as they succeeded in taking over Celcom at a relatively cheap price.

The court was satisfied that the plaintiff had the locus standi to bring this action on behalf of Celcom. The court was convinced that the plaintiff clearly satisfied all the procedural requirements under section $181 \mathrm{~A}$ and $181 \mathrm{~B}$ and thereby the court granted leave in favour of the plaintiff to bring an action on behalf of Celcom. The court observed that at the leave stage, it is not for the court to go into substantial issues on merits of the case; the court shall grant leave if it is satisfied that the plaintiff is acting in good faith and it appears prima facie to be in the best interest of the company that the application for leave to be granted.

\section{SOME HIGHLIGHTS OF THE MAIN ISSUES AND PRINCIPLES}

The need to address corporate abuses by directors and the need to improve the common law derivative action has led to the introduction of the statutory derivative action into the Companies Act $1965 .{ }^{12}$ The decision in Mohd Shuaib is significant as it constitutes the first case in Malaysia where the statutory derivative action was tested after its introduction in August 2007.

Section 181A identifies the persons who have locus standi to bring the action. In this case, the plaintiff was a former shareholder and

12 The amendment introducing the statutory derivative action is contained in sections 181A-181E of the Companies Act 1965. 
member of the company, Celcom. In determining whether the plaintiff fits into the definition of "complainant" in order to obtain the leave from the court to bring an action on behalf of Celcom, ${ }^{13}$ the court referred to section 181A(4)(b). ${ }^{14}$ The court was satisfied that the plaintiff ceased to be a member or shareholder as a result of his shares being compulsorily purchased by way of the mandatory general offer (MGO) under section 34 of the Securities Commission Act 1993. ${ }^{15}$ Being a former shareholder and member of Celcom, the plaintiff has a locus standi to apply for leave to commence the derivative action. It is worth noting that prior to the introduction of section 181A, a former member or shareholder was barred from commencing derivative action for want of standing under the common law. ${ }^{16}$ Currently, some countries that adopt statutory derivative action permit former members to bring an action on behalf of the company. ${ }^{17}$

13 Section 181A(1) provides that a complainant may, with the leave of the Court, bring, intervene in or defend an action on behalf of the company. Section 181A (4) (b) defines "complainant" to mean:

(a) a member of a company, or a person who is entitled to be registered as a member of a company;

(b) a former member of a company if the application relates to circumstances in which the member ceased to be a member;

(c) any director of a company; or

(d) the Registrar, in case of a declared company under Part IX.

Section 34 states that where a take-over offer by an offeror to acquire all the shares in an offeree company has, within four months after the making of the take-over offer, been accepted by the holders of $90 \%$ holding the shares of that class, the offeror may, at any time within two months after the take-over offer has been so accepted, give notice in the manner prescribed under the Takeover Code to any dissenting shareholder of its intention to acquire the remaining shares.

16 See, for example, Re Daon Development Corporation (1984) 54 BCLR 235.

17 The Australian Corporations Act, for example, allows an officer or former officer of a company and a member or former member as well as persons entitled to be registered as members to bring derivative claims. See s 236(1). In Singapore, on the other hand, section 216A of the Singapore Companies Act (Cap. 50, 1994 Rev. Ed.) allows any member of the company or a person who the court regards as appropriate to commence a statutory derivative action. 
Before the court can grant leave, the plaintiff as a complainant, must satisfy all the requirements under section 181B. Under this provision, an application for leave of court shall be made by originating summons and no appearance need to be entered. Section 181B (2) requires the complainant to give thirty days notice in writing to the directors of his intention to apply for leave of court under section 181A. The plaintiff had accordingly given the required notice of his intention to apply for such leave to file an action against the proposed defendants by a letter dated 14 December 2007.

In deciding whether or not leave should be granted Section $181 \mathrm{~B}(4)(\mathrm{b})$ requires the court to take into account whether the complainant is acting in good faith and it appears prima facie to be in the best interest of the company that the application for leave to be granted.

In order to satisfy that he is acting in good faith, it is necessary for the plaintiff to bring cogent evidence to establish clearly that the application is in fact brought in good faith. ${ }^{18}$ The court in Mohd Shuaib referred to the test for "good faith" as laid down in Primex Investments Ltd $v$ Northwest Sports Enterprise Ltd, ${ }^{19}$ a decision by the Supreme Court of British Columbia. The judge in Primex, Mr Justice Tysoe in finding the applicant had acted in good faith appears to have tied the requirement of 'good faith' to the test of the 'interest of the company.' In Primex there was no evidence the applicant was using the prospect of a derivative action as a threat in order to extract some advantage from the company. Tysoe $\mathrm{J}$ in Primex also indicated that an applicant advancing self-interest is not necessarily acting in bad faith.

The court was of the view that the proposed action in Mohd Shuaib seeks to restore Celcom as an independent company and return the benefits of being a shareholder of Celcom to the shareholders prior to the MGO. The court observed that after the merger, Celcom lost its independence and became a wholly owned subsidiary of Telekom. Newspaper reports indicate that Celcom was a major force within the Telekom group and the future of Telekom depends to a large extent, on the continued growth and success of Celcom. ${ }^{20}$ The former shareholders

\footnotetext{
$18 \quad$ Tremblett v S.C.B. Fisheries Ltd [1993] 116 Nfld. \& P.E.I.R 139.

$19 \quad$ [1995] Can LII 717 (BCSC).

$20 \quad$ Supra n. 1 at 879 . See also p. 881 where the exhibits and defendant's affidavit No 2 show that Celcom was a vibrant company with a stronger customer base than TM Cellular. The court was convinced that if Celcom
} 
were deprived of their membership of Celcom as a result of the alleged misrepresentation and conspiracy. It also includes the dissenting shareholders who had to sell their shares to Telekom through the compulsory acquisition power exercised by Telekom.

It is interesting to note that the court observed that the plaintiff may be acting out of self-interest in wanting to bring the derivative action; the self-interest was to maximise the value of his shares in Celcom. ${ }^{21}$ The defendants argue that the plaintiff cannot meet the good faith test as the application was purportedly not made in good faith and was for a collateral purpose and/or an ulterior motive. The defendants' central argument is that the real motivation underlying this application is to aid the plaintiff in his personal action and to pressure the Defendants to discontinue their legal action against the plaintiff's associates. The defendants describe this application as just one of the series of tactics used by the plaintiff in ongoing disputes between it and the plaintiff and between it and the plaintiff's associates. The court referred to Agus Irawan $v$ Toh Teck Chye ${ }^{22}$ and reiterated Choo Han Teck JC's observation that the court is entitled to assume that every party who comes to court with a reasonable and legitimate claim is acting in good faith. The burden of proof then lies on the opponent to show that the applicant did act in bad faith. The court was of the view that the defendant in Mohd Shuaib failed to prove that the plaintiff was acting in bad faith. The court, however, observed that the plaintiff's self-interest coincided with the interest of Celcom. ${ }^{23}$ But in the court's view, this fact alone is not sufficient to prove that the plaintiff was acting in bad faith.

The court further stated that anything that benefits the company (Celcom) will indirectly benefit the shareholders by increasing the share value. ${ }^{24}$ The court further observed that it is hard to imagine a situation where a shareholder will not have a self-interest in wanting the company (Celcom) to prosecute an action which is in its interest to prosecute. The court stated that if the proposed action itself is meritorious and legitimate,

\footnotetext{
were to be left to its own devices, it would not have merged with TM Cellular.

Ibid at 875.

[2002] 2 SLR 198.

Supra n. 21.

The court referred to Richardson Greenshields v Kalmacoff [1995] 22

O.R. (3d) 577 (Ont. C.A) and Primex Investment Ltd .
} 
the court is not overly concerned that the plaintiff's self-interest or other consideration may have motivated the application. ${ }^{25}$

The court proceeded to examine section $181 \mathrm{~B}(4)$ (b) which requires the court to take into account whether it appears prima facie to be in the best interest of the company that the application for leave to be granted. The court takes that "to mean that what is sufficient at this stage is that a prima facie arguable case be shown to subsist." ${ }^{\prime 26}$ It was not necessary for proof of the substantial issues on merits. So long as the application is not frivolous and vexatious and there is some substance on the grounds supporting the application, the court may grant the leave.

The Court referred to several cases to illustrate the test of whether an action is prima facie in the interests of the company. In Discovery Enterprises Inc. v Ebco Industries Ltd., ${ }^{27}$ citing Williams $\mathrm{J}$ where he observed:

The real question here is whether in the circumstances of this case, 'it is prima facie in the interests of the company that the action be brought' (section 222(3) (c)). It will be noted that the Legislature has said that it is sufficient to show that the action sought is prima facie in the interest of the company and does not appear to require that the applicants prove a prima facie case. .... This application decides nothing more than whether the applicant has adduced sufficient evidence which on the face of that evidence discloses that it is, so far as can be judged from the first disclosure, in the interests of the company to pursue the action.

In Carr v Cheng ${ }^{28}$ the Supreme Court of British Columbia, dealing with the same subject matter observed that "the judge hearing an application for leave to commence an action, cannot try the action... where the applicant is acting in good faith and otherwise has the status to commence the action, and where the intended action does not appear

\footnotetext{
25 The court referred to Seow Tiong Siew v Kwok Low Mong Lawrence [2000] 4 SLR 768.

$26 \quad$ See Mohd Shuaib Ishak, supra n. 1 at 879.

27 [1997]B.C.T.C. LEXIS 5338.

28 [2005] BCSC 445.
} 
frivolous and vexatious and could reasonably succeed; and where such action is in the interests of the shareholders, then leave to bring the action should be given."

The authorities referred to by the court point to a conclusion that at the leave stage, the court is not called upon to adjudicate disputes of fact and inference but to determine if there is prima facie merit in the proposed action and that the application is not frivolous and vexatious. ${ }^{29}$

Thus, in determining whether it is in the interest of Celcom that the leave be granted, the court in Mohd Shuaib discussed the alleged breach of duties by the directors. It is an established principle that directors owe duties to the company and not to the shareholders individually. ${ }^{30}$ However, where they assume a special relationship with the shareholders, the directors owe duties to the shareholders. ${ }^{31}$ In a takeover context, the directors are under an obligation to appoint an advisor to prepare an independent advice circular and to advise the shareholders accordingly. The advice given by the directors will normally persuade the shareholders to either sell or retain their shares in the company. The court referred to Gething $v$ Kilner ${ }^{32}$ where it was held that "the directors of an offeree company owed a duty to their shareholders which included the duty to be honest and not to mislead; any minority shareholders of such company could properly complain if they are being wrongfully subjected to the power of compulsory purchase by the offeror."

In this case, the directors owe a duty to act in the interest of the shareholders and not to mislead them over the buy out and the ARSA. The directors should also have had the shareholders' interests at heart to enable the shareholders to obtain the best price possible for their shares. The fact that the directors allowed the MGO to be made at RM2.75 per share instead of RM7 constitutes, in the view of the court, a sufficient ground to believe that the directors had breached their duties to Celcom and its shareholders. Their failure to disclose material matters when advising the shareholders goes against the takeover Code. ${ }^{33}$ Ramly $\mathrm{J}$

$29 \quad$ See Teo Gek Luang v Ng Ai Tiong [1999] 1 SLR 434; Association of Bank Officers Peninsular Malaysia v Malayan Commercial Banks Association [1990] 2 CLJ 734.

Percival v Wright [1902] 2 Ch. 421.

Peskin v Anderson [2001] 1 BCLC 372.

[1972]1 All ER 1166.

See section 14 of the Code on Take-overs and Mergers. 
was convinced that Celcom will not bring the proposed action as allegations made and remedies will be sought in the course of the proposed action against the directors of Celcom as well as the ultimate holding company of Celcom, Telekom Malaysia Bhd and the Telekom directors.

It is also important to note that bearing in mind the fact that Celcom was under the control and management of Telekom and became a subsidiary of Telekom Enterprise before the offer document was posted, made Celcom a nominee of Telekom. The court pointed out that difficulties arise in situations where a nominee director represents the interests of particular persons; in this case, Celcom has become nominee of Telekom by the fact that Telekom has a significant stake in Celcom. However, cases reported in England and Malaysia has adopted a strict approach regarding the duties of nominee directors. In Scottish Co-Operative Wholesale Society $v$ Meyer ${ }^{34}$ Lord Denning held that where the interests of the appointers and the company do not coincide, a nominee director is bound to put the interests of the company ahead of the sectional interest he represents. Regardless of the fact that Celcom was in effect a nominee of Telekom at the time the offer document was posted, the directors are still under a duty to act in the best interests of Celcom.

The court went further to consider the effect of the SPA and the MGO. In this case, the court stated that if the proposed action is successful, the contracts made in connection with the MGO and the SPA and all contracts for the purchase of or subscription for Celcom shares under the MGO may be considered illegal for breach of s 24 of the Contracts Act 1950. The MGO and the conditional SPA would have to be unwound and Celcom would be restored to its position of being an independent company instead of just being a subsidiary of Telekom. The court disagreed with the defendants' contention that it would not be in the best interest of Celcom to unwind the entire transaction. The court ruled that no illegal act can be immune from challenge merely because it has been completed and unwinding it would be too troublesome. ${ }^{35}$

When considering whether there was indeed conspiracy as alleged by the plaintiff, the court observed that it is apparent that the proposed defendants may have wrongly and maliciously conspired and combined among themselves to injure Celcom and its shareholders. The

\footnotetext{
$34 \quad$ [1958] 3All ER 66.

$35 \quad$ Mohd Shuaib Ishak, supra n. 1 at 881.
} 
court stated "it is apparent that the proposed defendants had wrongfully and maliciously conspired and combined amongst themselves with the real and predominant purpose of benefitting Telekom and Telekom Enterprise and parties acting in concert with them to enable them to make the MGO at an offer price of RM2.75 per Celcom share instead of RM7.00 and causing losses to Celcom and its shareholders.” The court discovered that Telekom already had a preconceived plan to takeover based on the fact that by the time the SPA was signed, Telekom already had the effective control of Celcom and had appointed their nominees to the Board of Celcom to take control. ${ }^{36}$ In the court's view, all the ingredients of the alleged conspiracy are present and have been pleaded properly in the proposed pleadings. The court stressed that at the leave stage the plaintiff's obligation is to plead materials fact; not evidence of law.

The court was convinced that the proposed action by Mohd Shuaib seeks to restore Celcom as an independent company and return the benefits of being a shareholder of Celcom to the shareholders prior to the takeover. The court was also of the view that there were reasonable grounds that Telekom was instrumental in causing Celcom to enter into the conditional SPA and to breach the ARSA thereby giving rise to the award under the ICC Arbitration. Further, it appears that the merger of Celcom with TM cellular caused damage to Celcom; it obviously saved TM Cellular and thus benefitted Telekom. It also appears that Celcom would have been much better off and stronger on its own. Therefore, the court was satisfied that the plaintiff had acted in good faith and had demonstrated that it was prima facie in the interest of the company that the action be brought. The court stressed that at the leave stage the threshold requirement or guiding principles for leave to bring an action on behalf of the company under section 181A should not be narrowed down so extremely as not to impose or place undue burden or shackles on the plaintiff to such an extent that it may eventually frustrate the object of the procedural rules for seeking leave.

$36 \quad$ This can be seen from the admission made by CIMB that it was instructed to advise Telekom on the SPA and the MGO before Telekom had even gained control of Celcom. 


\section{SOME OBSERVATIONS}

Mohd Shuaib is significant in paving the way for shareholders, especially minority shareholders, to seek remedies on behalf of a corporation against abuses committed by the directors against the corporation.

The introduction of the new statutory derivative action indicates attempts by the legislature to address the setbacks of the common law derivative action. The new statutory derivative action has also encouraged shareholders to defend their company against wrongdoing by those in control by allowing the court to make appropriate orders including an order requiring the company to pay reasonable legal fees and disbursement incurred by the complainant in connection with the action. ${ }^{37}$

The directors who breached their duties to the company will have to compensate the company. Due to this fact, some argue that in the long run, the majority shareholders will benefit from the actions though it may be the majority shareholders or the directors who had caused the company to suffer loss. However, some argue that if maintaining good corporate governance is essential to investor confidence, there must be effective ways of deterring managerial misconduct. ${ }^{38}$ Statutory derivative action is seen as a tool to enhance managerial accountability by deterring wrongful conduct. In Westgoal Resources NL v Precious Metals Australia $L_{t d}{ }^{39}$ Heenan J observed that "the action for relief... under the statutory derivative action [is a remedy] to vindicate an interest of the company as a whole, with consequent benefit to all current shareholders or members."

$37 \quad$ Section $181 \mathrm{E}(1)$ specifies the various order which the court thinks appropriate. Sub-section (d) allows the court to order the company "to pay reasonable legal fees and disbursements incurred by the complainant in connection with the application or action or pending the grant of the leave of any injunction by the court hearing the application for leave." Alternatively, sub-section (e) allows for indemnification for costs of the complainant, the company or any other person for proceedings under the derivative action.

CLERP Proposals for Reform, Directors' Duties and Corporate Governance: Facilitating Innovation and Protecting Investors (Paper No 3, 1997) at pages 7-11. [2002] WASC 221. 
It is interesting to note that in Mohd Shuaib, the action brought by the former shareholder, if successful, will not only benefit the company but also the shareholders or former shareholders who have suffered loss as a result of the wrongdoing of the directors. They may recover the monetary loss they suffered as a result of relying on the advice of the directors. This is so because in a takeover scenario, the directors of the target company play the role of a middle man whose advice will influence the decision of the shareholders whether to sell or to retain their shares. Further, as explained above if the transactions were to be unwound on the ground of illegality, the former shareholders will directly benefit from this action.

Mohd Shuaib is significant as it constitutes the first application made under the statutory derivative action after its introduction in August, 2007. This case put to test the statutory derivative action and allows the evaluation of its benefit to shareholders, including former shareholders in comparison to the common law derivative action.

It is worth noting that on 27 March 2009, the Court of Appeal granted an appeal by Celcom to set aside the Order of the High Court dated 9 July 2008 with costs. The grounds for the appeal are, however, unavailable at the time this case note is submitted. 